\title{
Kinetic, Isotherm and Thermodynamic Studies on the Adsorption Behavior of Atrazine onto Sheep Manure-Derived Biochar
}

\author{
Yixin Lu" ${ }^{1,2}$, Jiao Chen ${ }^{1,2}$, Jianqiang Zhang1*, Chenchen Fu' \\ ${ }^{1}$ Faculty of Geosciences and Environmental Engineering, Southwest Jiaotong University, Chengdu, China \\ ${ }^{2}$ Department of Architectural and Environmental Engineering, Chengdu Technological University, Chengdu, China
}

Received: 7 May 2018

Accepted: 5 July 2018

\begin{abstract}
Experimental and theoretical studies have been conducted to investigate the adsorption of atrazine in aqueous solutions by sheep manure-derived biochar synthesized at $650^{\circ} \mathrm{C}$ (SMB650). The results of characterization analysis showed that SMB650 possessed large specific surface area and was rich in pore structure and functional groups. The removal efficiency of atrazine by SMB650 was 95.3\% under the optimum conditions, of which contact time, initial atrzaine concentration, initial solution $\mathrm{pH}$, SMB650 dosage and temperature were $150 \mathrm{~min}, 1500 \mu \mathrm{g} / \mathrm{L}, 3.0,1.6 \mathrm{~g} / \mathrm{L}$ and $25^{\circ} \mathrm{C}$, respectively. The results of kinetic and isotherm studies revealed that the pseudo second-order and the Freundlich model fit the experimental data best $\left(R^{2}>0.98\right)$. The adsorption of atrazine onto SMB650 belonged to multi-molecular layer adsorption. The calculated thermodynamic parameters like free energy change $\left(\Delta G^{\theta}\right)$, enthalpy change $\left(\Delta H^{\ominus}\right)$ and entropy change $\left(\Delta S^{\theta}\right)$ were -7.8730 to $-6.2976 \mathrm{~kJ} / \mathrm{mol}$, $17.2179 \mathrm{~kJ} / \mathrm{mol}$ and $0.0788 \mathrm{~kJ} /(\mathrm{mol} \cdot \mathrm{K})$, respectively, indicating that the adsorption process of atrazine onto SMB650 was spontaneous, endothermic and entropy-increased. The present study showed that the sheep manure-derived biochar could be used as a promising adsorbent for the removal of atrazine from aqueous solutions.
\end{abstract}

Keywords: atrazine adsorption; kinetics; isotherms; thermodynamics; sheep manure-derived biochar

\section{Introduction}

Atrazine (2-chloro-4-[ethylamino]-6-[isopropylamino] -s-triazine) is a selective herbicide that has been widely used worldwide due to its low cost and good weeding effect. However, owing to the characteristics such as stable chemical structure, superficial mobility, long

*e-mail: zhjiqicn@swjtu.cn half-life and high leaching potential, atrazine has been frequently detected in the surface and ground water in many countries and regions [1-3]. Continuous exposure to atrazine may inhibit the growth of plants and animals. Moreover, atrazine can be absorbed and accumulated by the human body through food chain enrichment, which would disrupt the endocrine systems, alter immune response, retard sexual and embryo development and induce the mammary gland or cancer $[4,5]$. Therefore, the removal of atrazine from water 
has been considered a significant and urgent issue in wastewater treatment.

At present, the main methods to remove atrazine include adsorption [6-9], UV and UV/MW photolysis [10], ozonation [11] and Fenton-like process [12]. Among these methods, adsorption is favored by researchers because of its advantages such as low cost, high efficiency and simple operation. Biochar is the product of biomass by pyrolysis and carbonization under oxygen-limited conditions. It possesses high specific surface area, rich pore structure and abundant functional groups, which together have led to its great adsorption potential [13-15]. Recently, a variety of biochars have been reported to apply to the removal of atrazine from aqueous solutions. Wang et al. [8] prepared wheat strawderived biochar (WS750) via pyrolysis at $750^{\circ} \mathrm{C}$ and found that the sorption quantity of atrazine by WS750 could reach $12.0 \mathrm{mg} / \mathrm{g}$. Tan et al. [16] obtained cornstraw biochar via slow pyrolysis at $500^{\circ} \mathrm{C}$ and suggested that its maximum sorption capacity for atrazine was $1.94 \mathrm{mg} / \mathrm{g}$. Zhang et al. [17] reported that the sludge biochars prepared at $400^{\circ} \mathrm{C}$ for 2 hours had the greatest atrazine adsorption and the adsorption equilibrium time was about 36 hours. However, most research concerning the adsorption of atrazine has been limited to biochars prepared by plant residues or excess sludge. Studies on biochars derived from livestock manure for atrazine adsorption have rarely been reported. Currently, sheep farming has developed rapidly in many countries, including Poland, India and China. The amount of sheep manure increased sharply with increasing numbers of sheep. It will pose great pressure on the ecological environment if sheep manure cannot be effectively treated or reused [18-20]. Although sheep manure contains a certain amount of fertilizer, when it is not fermented, the utilization rate of the plant is low, and it is easy to cause the plant to burn roots and seedlings. Moreover, the germs, worm eggs and parasites in sheep manure may also cause the spread of diseases and insect pests. Thus, sheep manure is not suitable for direct use as fertilizer in the soil. If the sheep manure can be used to produce biochar to adsorb atrazine, it will only reduce environmental pollution but also achieve waste recycling.

In this study, the adsorption ability of biochar produced from sheep manure to atrazine from aqueous solutions was investigated. The physicochemical properties of sheep manure-derived biochar were characterized. The main factors (initial solution $\mathrm{pH}$, biochar dosage, contact time, initial atrazine concentration and temperature) that affect adsorption effect were evaluated using batch experiments. Based on this, the adsorption mechanism was analyzed by kinetic, isothermic and thermodynamic models. The purpose of this study was to develop an innovative, efficient, low-cost and environmentally friendly adsorbent for the removal of atrazine from wastewater and provide a theoretical basis for the resource utilization of sheep manure.

\section{Materials and Methods}

\section{Reagents and Chemicals}

Atrazine (with purity $>97 \%$, Fig. 1) procured from Aladdin Chemical Reagent Co. Ltd, was used in the present experiment. Certain amount of atrazine was dissolved in deionized water to prepare $20 \mathrm{mg} / \mathrm{L}$ stock solution. The stock solution was diluted based on the experimental needs. The initial $\mathrm{pH}$ of atrazine solution was adjusted by adding $0.1 \mathrm{~mol} / \mathrm{L} \mathrm{NaOH}$ or $0.1 \mathrm{~mol} / \mathrm{L}$ $\mathrm{HCl}$ solutions. All the chemical reagents involved were analytically pure and the water was deionized.

\section{Preparation of Adsorbent}

The sheep manure was collected from a farm in Hongya County, Sichuan Province, China. The manure was processed by a pulverizer and ground through a 60 mesh sieve after drying and picking out impurities. We dried the sifted material in an $85^{\circ} \mathrm{C}$ oven to a constant weight and took an appropriate amount to the crucible, and then put it into the muffle furnace after compacting and covering. It was then heated up to $650^{\circ} \mathrm{C}$ at a rate of $20^{\circ} \mathrm{C} / \mathrm{min}$ and maintained constant temperature for $180 \mathrm{~min}$ before shutting down the muffle furnace and removing the pyrolysis products after cooling to room temperature. To remove the ash of the pyrolysis products, $200 \mathrm{~mL} \mathrm{HCl}$ solution of $1.0 \mathrm{~mol} / \mathrm{L}$ was added to $10 \mathrm{~g}$ pyrolysis products, the solution was oscillated at $150 \mathrm{r} / \mathrm{min}$ for $30 \mathrm{~min}$ and repeated three times. The products were sifted and dried in a $105^{\circ} \mathrm{C}$ oven to a constant weight after water washing to neutral. The sheep manure-derived biochar (SMB650) was successfully prepared after the products were cooled and passed through a 100-mesh sieve.

\section{Adsorption Experiments}

Batch experiments were conducted in the present study. In each experiment, a $50-\mathrm{mL}$ atrazine solution of a certain mass concentration was placed in a $100-\mathrm{mL}$ conical flask. A certain quantity of SMB650 was added and the initial solution $\mathrm{pH}$ value was then adjusted, and magnetic stirring was used to accelerate the

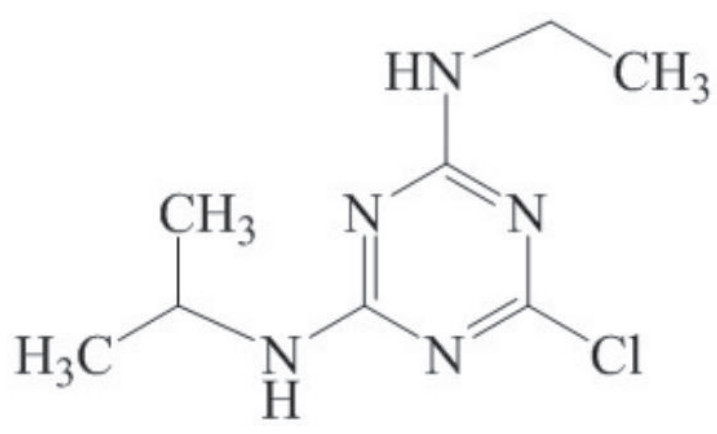

Fig. 1. Molecular structure of atrazine. 
equilibrium in the adjustment process. The suspension was oscillated at $150 \mathrm{r} / \mathrm{min}$ for a certain period of time. The $\mathrm{pH}$ value of the solution was regularly detected during the experiment, and was kept constant by adding $0.1 \mathrm{~mol} / \mathrm{L} \mathrm{HCl}$ or $\mathrm{NaOH}$. After the oscillation was over, the suspension was centrifuged at $4000 \mathrm{r} / \mathrm{min}$ for $10 \mathrm{~min}$ and then filtered through a $0.45-\mu \mathrm{m}$ filter membrane. The filtrate was used to analyze for the residual atrazine.

\section{Analysis Methods}

The C, H, N and O contents of SMB650 were tested by elemental analyzer (VARIO EL cube, Elementar, Germany). The specific surface area (SSA), total pore volume (TPV) and average pore diameter (APD) of SMB650 were tested by specific surface area analyzer (NOVA4000e, Quantachrome, America). The surface topography characteristics of SMB650 were tested by a field emission scanning electron microscope (SUPRA40, ZEISS, Germany). The surface functional groups of SMB650 were tested by a Fourier infrared spectrometer (FTIR Spectrum100, Perkin Elmer, America). The concentration of atrazine was tested by high-performance liquid chromatography (Waters 2695-2996, Alliance, America). The analysis was run at $225 \mathrm{~nm}$ using methanol: water (60: 40, v/v) as mobile phase with a flow velocity of $0.8 \mathrm{~mL} / \mathrm{min}$ and a column temperature of $40^{\circ} \mathrm{C}$.

The removal efficiency $(\eta, \%)$ and adsorption amount $\left(q_{t}, \mu \mathrm{g} / \mathrm{g}\right)$ of atrazine adsorbed onto SMB650 in each test were evaluated using the following equations:

$$
\begin{gathered}
\eta=\left(C_{0}-C_{e}\right) \times 100 \% / C_{0} \\
q_{\mathrm{t}}=\left(C_{0}-C_{\mathrm{e}}\right) V / m
\end{gathered}
$$

...where $C_{0}(\mu \mathrm{g} / \mathrm{g})$ is the initial concentration of atrazine, $C_{e}(\mu \mathrm{g} / \mathrm{g})$ is the equilibrium concentration of atrazine, $V$ $(\mathrm{mL})$ is the volume of suspension, $m(\mathrm{~g})$ is the mass of SMB650 and $t(\mathrm{~min})$ is the contact time.

\section{Results and Discussion}

\section{Physicochemical Properties of SMB650}

Elemental analyses (Table 1) showed that the elemental content of SMB650 decreased in the order $\mathrm{C}>\mathrm{O}>\mathrm{N}>\mathrm{H}$. Generally, the ratios of $\mathrm{H} / \mathrm{C}, \mathrm{O} / \mathrm{C}$ and $(\mathrm{O}+\mathrm{N}) / \mathrm{C}$ are recognized as indices for the aromaticity and polarity of adsorption materials $[21,22]$. In the present study, the relatively lower ratios of $\mathrm{H} / \mathrm{C}, \mathrm{O} / \mathrm{C}$ and $(\mathrm{O}+\mathrm{N}) / \mathrm{C}$ indicated that SMB650 was of high aromaticity and stability. Besides, the SSA, TPV and APD of SMB650 was $189.35 \mathrm{~m}^{2} / \mathrm{g}, 0.252 \mathrm{~cm}^{3} / \mathrm{g}$ and $12.43 \mathrm{~nm}$, respectively. The result of SEM analysis (Fig. 2) also showed that SMB650 had rough texture with uneven surface and a large number of irregular pores. The large

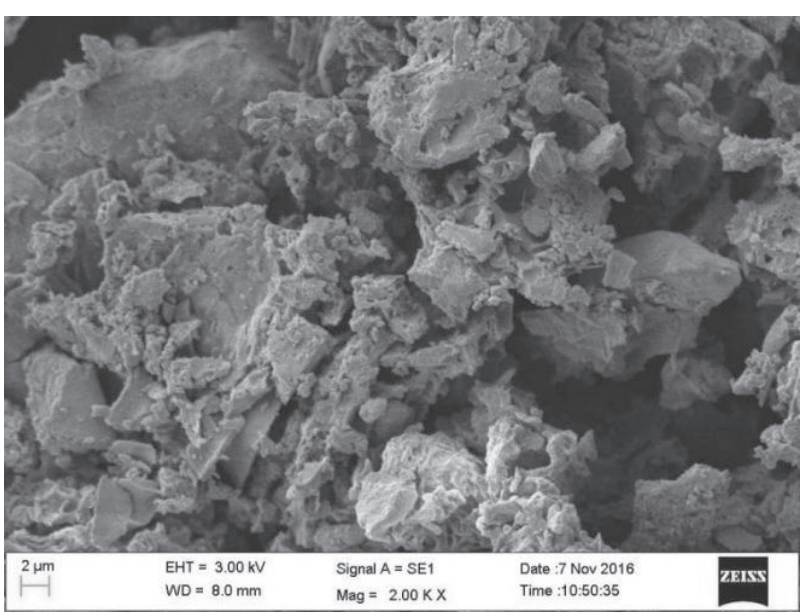

Fig. 2. SEM image of SMB650.

specific surface area and pore structure provided good conditions for atrazine adsorption onto SMB650.

The FTIR spectrogram of SMB650 is shown in Fig. 3. It can be seen that the stretching vibration of hydroxyl groups $(-\mathrm{OH}), \mathrm{C}-\mathrm{H}$, aromatic ring $(\mathrm{C}=\mathrm{C}$ and $\mathrm{C}=\mathrm{O}$ ) and $\mathrm{C}-\mathrm{O}$ appeared at $3409 \mathrm{~cm}^{-1}, 2920 \mathrm{~cm}^{-1}$, $1603 \mathrm{~cm}^{-1}$ and $1088 \mathrm{~cm}^{-1}$, respectively, and the bending vibration of C-H appeared at $795 \mathrm{~cm}^{-1}$. The result showed that the surface of SMB650 contained rich functional groups and aromatic structures, which provided a good basis for the adsorption of atrazine.

\section{Preliminary Adsorption Studies}

\section{Effect of Initial Solution $\mathrm{pH}$}

The solution $\mathrm{pH}$ not only influences the physicochemical properties of the adsorbent but also affects the charge of adsorbate presented in the solution [23-25]. The effect of initial solution $\mathrm{pH}$ on the adsorption of atrazine onto SMB650 was studied using $1500 \mu \mathrm{g} / \mathrm{L}$ atrazine concentration under the condition

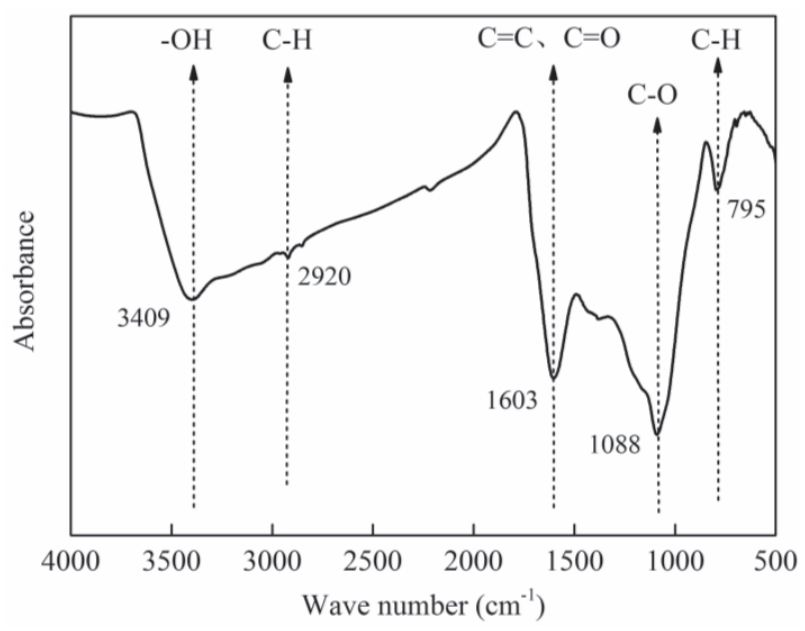

Fig. 3. FTIR spectra of SMB650. 
a)
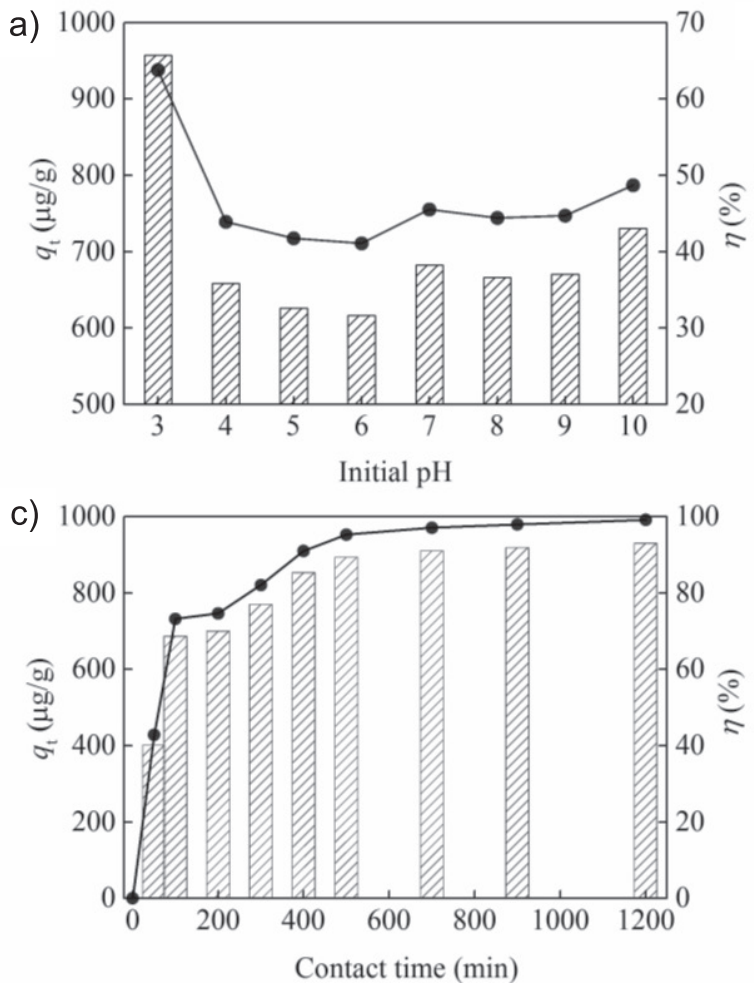
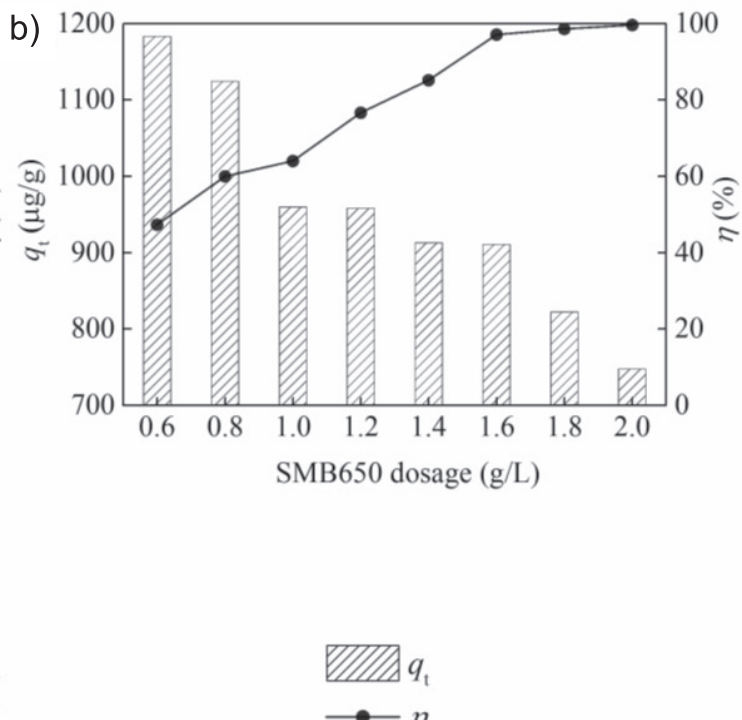

Fig. 4. Effects of different variables on adsorption efficiency: a) initial solution pH; b) SMB650 dosage; c) contact time.

of $1.0 \mathrm{~g} / \mathrm{L}$ SMB650 dosage, $\mathrm{pH} \quad 3.0-10.0$ at $25^{\circ} \mathrm{C}$ (Fig. 4a). It should be noted that in order to avoid the dilution caused by the excessive addition of $\mathrm{HCl}$ or $\mathrm{NaOH}$ when the $\mathrm{pH}$ of the solution was adjusted, and to save the cost of $\mathrm{HCl}$ or $\mathrm{NaOH}$ dosage, the solution $\mathrm{pH}$ in this study was investigated from 3.0 to 10.0.

As can be seen, SMB650 showed the best adsorbing effect when the $\mathrm{pH}$ value was 3.0, with the adsorption amount of atrazine up to $957.019 \mu \mathrm{g} / \mathrm{g}$ and the removal efficiency up to $63.8 \%$. Comparatively speaking, the removal efficiency showed a $55.4 \%$ decrease when $\mathrm{pH}$ value was 6.0. On the one hand, since atrazine was a weakly alkaline substance its solubility decreased with the increase of $\mathrm{pH}$ value, and acidic condition was more favorable for adsorption. On the other hand, the atrazine was mainly in molecular form in solution when the $\mathrm{pH}$ value was near or less than its acid dissociation constant $\left(\mathrm{p} K_{a}=1.68\right)$. Because the adsorption of atrazine was mainly carried out by proton carboxyl group and molecular morphology, the adsorption reached a maximum when the initial solution $\mathrm{pH}$ value was 3.0.

\section{Effect of Biochar Dosage}

One of the parameters that significantly affect adsorption capacity is the dosage of adsorbent [26]. The effect of SMB650 dosages on the adsorption capacity was studied by contacting $50 \mathrm{~mL}$ of atrazine solution $(1500 \mu \mathrm{g} / \mathrm{L})$ for SMB650, keeping the contact time for $700 \mathrm{~min}$ at $25^{\circ} \mathrm{C}$ with the optimum $\mathrm{pH}$ of 3.0 .
A different amount of SMB650 (0.6-2.0 g/L) was added and the results are shown in Fig. 4b).

It was obvious that the removal efficiency of atrazine increased with the increase of SMB650 dosage. For instance, the removal efficiency of atrazine was up to $99.7 \%$ when the SMB650 dosage was $2.0 \mathrm{~g} / \mathrm{L}$. On the contrary, the adsorption capacity of SMB650 for atrazine decreased with the increase of the biochar dosage. When the SMB650 dosage increased from 0.6 to $2.0 \mathrm{~g} / \mathrm{L}$, the adsorption amount of atrazine decreased from 1183.133 to $747.375 \mu \mathrm{g} / \mathrm{g}$. The removal efficiency was lower when the biochar amount was insufficient to adequately adsorb atrazine. Nevertheless, the excessive amount of biochar could result in spare adsorption sites, leading to the adsorption capacity decreasing because the biochar could not be fully utilized. Taking the removal efficiency, adsorption capacity and economical efficiency into overall consideration, the optimum SMB650 dosage for follow-up experiments was set to be $1.6 \mathrm{~g} / \mathrm{L}$. Under this condition, the adsorption amount of atrazine onto SMB650 was $910.603 \mu \mathrm{g} / \mathrm{g}$ and the removal efficiency of atrazine was $97.1 \%$.

\section{Effect of Contact Time}

Contact time is one of the key parameters in the adsorption process [27]. In the present study, contact time ranged from 50 to $1200 \mathrm{~min}$. Other experimental parameters were $1500 \mu \mathrm{g} / \mathrm{L}$ atrazine, $\mathrm{pH}$ 3.0, SMB650 dosage $1.6 \mathrm{~g} / \mathrm{L}$ and temperature $25^{\circ} \mathrm{C}$. The results of contact time affect are shown in Fig. 4c). 
Table 1. Basic characteristics of SMB650.

\begin{tabular}{|c|c|c|}
\hline \multicolumn{2}{|c|}{ Parameter } & Value \\
\hline \multicolumn{2}{|c|}{ Yield (\%) } & 42.86 \\
\hline \multirow{2}{*}{ Ash content (\%) } & 19.65 \\
\hline \multirow{3}{*}{ Elemental analysis (\%) } & $\mathrm{C}$ & 64.73 \\
\cline { 2 - 3 } & $\mathrm{H}$ & 1.92 \\
\cline { 2 - 3 } & $\mathrm{O}$ & 10.64 \\
\cline { 2 - 3 } & $\mathrm{N}$ & 2.41 \\
\hline \multirow{3}{*}{ Atomic ratio } & $\mathrm{H} / \mathrm{C}$ & 0.030 \\
\cline { 2 - 3 } & $\mathrm{O} / \mathrm{C}$ & 0.164 \\
\cline { 2 - 3 } & $(\mathrm{O}+\mathrm{N}) / \mathrm{C}$ & 0.202 \\
\hline SSA $\left(\mathrm{m}^{2} / \mathrm{g}\right)$ & & 189.35 \\
\hline TPV $\left(\mathrm{cm}^{3} / \mathrm{g}\right)$ & & 0.252 \\
\hline \multicolumn{2}{|c|}{$\mathrm{APD}(\mathrm{nm})$} & 12.43 \\
\hline
\end{tabular}

It could be seen that the adsorption of atrazine onto SMB650 consisted of three stages: rapid adsorption (50-100 min), slow diffusion (100-500 $\mathrm{min})$ and adsorption equilibrium (500-1200 $\mathrm{min})$. In the rapid adsorption stage, the adsorption sites of the biochar were abundant and the adsorption rate was very high. The removal efficiency of atrazine was up to $73.2 \%$ at the end of this stage. As the contact time prolonged, atrazine began to slowly spread to the internal pores of biochar and the adsorption rate gradually slowed. When the contact time was further extended, the remaining atrazine concentration in the solution was low and the mass transfer power was weak, so the adsorption was gradually approaching equilibrium. Hence, $500 \mathrm{~min}$ was considered as the optimal adsorption time. The adsorption amount of atrazine at this experimental time was $893.538 \mu \mathrm{g} / \mathrm{g}$ and removal efficiency was $95.3 \%$.

\section{Adsorption Kinetics}

To better analyze the behavior of atrazine adsorption onto SMB650, the adsorption of different initial atrazine concentrations (1500, 2000 and $2500 \mu \mathrm{g} / \mathrm{L})$ were studied. The adsorption data were simulated using the pseudo first-order, pseudo second-order, intra-particle diffusion and Elovich models. The equations can be described as follows:

Pseudo first-order model: $\ln \left(q_{e}-q_{t}\right)=\mathrm{h} q_{e}-k_{1} t$

Pseudo second-order model: ${ }^{t /} q_{t}=t / q_{e}+1 / k_{2} q_{e}^{2}$

Intra-particle diffusion model: $q_{t}=k_{3} t^{1 / 2}+C$

Elovich model: $q_{t}=(1 / \beta) \mathrm{h}(\alpha \cdot \beta)+(1 / \beta) \mathrm{h}(t)$

...where $q_{\mathrm{e}}(\mu \mathrm{g} / \mathrm{g})$ and $q_{\mathrm{t}}(\mu \mathrm{g} / \mathrm{g})$ are the adsorption amount at equilibrium and time $t(\mathrm{~min})$, respectively; $k_{1}\left(\min ^{-1}\right), k_{2}[\mathrm{~g} /(\mu \mathrm{g} \cdot \mathrm{min})]$ and $k_{3}\left[\mu \mathrm{g} /\left(\mathrm{g} \cdot \mathrm{min}^{0.5}\right)\right]$ are the rate constant of pseudo first-order, pseudo second-order
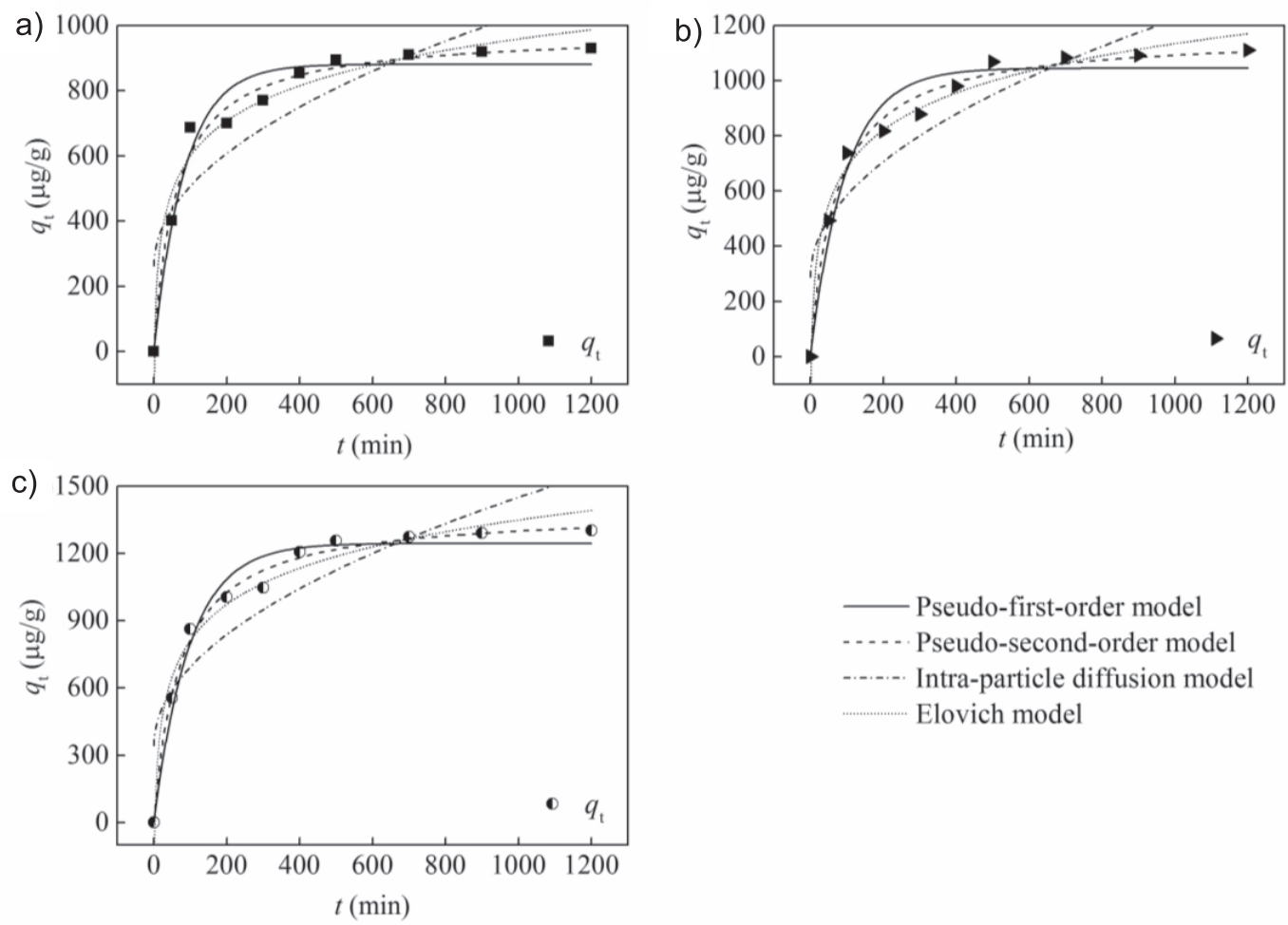

Fig. 5. Kinetic curves of atrazine adsorption onto SMB650 (initial atrazine concentration: a) $1500 \mu \mathrm{g} / \mathrm{L}$; b) $2000 \mu \mathrm{g} / \mathrm{L}$; c) $2500 \mu \mathrm{g} / \mathrm{L}$ ). 
Table 2. Kinetic parameters for the adsorption of atrazine onto SMB650.

\begin{tabular}{|c|c|c|c|c|}
\hline \multirow{2}{*}{ Kinetic model } & \multirow{2}{*}{ Parameter } & \multicolumn{3}{|c|}{ Initial atrazine concentration $(\mu \mathrm{g} / \mathrm{L})$} \\
\cline { 2 - 4 } & & 1500 & 2000 & 2500 \\
\hline \multirow{3}{*}{ Pseudo-first-order } & $q_{\mathrm{e}}(\mu \mathrm{g} / \mathrm{g})$ & 880.690 & 1044.792 & 1244.399 \\
\cline { 2 - 5 } & $k_{1}\left(\mathrm{~min}^{-1}\right)$ & 0.0118 & 0.0104 & 0.0103 \\
\cline { 2 - 5 } & $R^{2}$ & 0.9599 & 0.9554 & 0.9713 \\
\hline \multirow{3}{*}{ Pseudo-second-order } & $q_{\mathrm{e}}(\mu \mathrm{g} / \mathrm{g})$ & 979.500 & 1169.103 & 1392.681 \\
\cline { 2 - 5 } & $k_{2}[\mathrm{~g} /(\mu \mathrm{g} \cdot \mathrm{min})]$ & $1.644 \times 10^{-5}$ & $1.216 \times 10^{-5}$ & $1.003 \times 10^{-5}$ \\
\hline \multirow{3}{*}{ Intra-particle diffusion } & $R^{2}$ & 0.9819 & 0.9875 & 0.9918 \\
\cline { 2 - 5 } & $k_{3}\left[\mu \mathrm{g} /\left(\mathrm{g} \cdot \mathrm{min}^{0.5}\right)\right]$ & 262.9421 & 288.1795 & 343.1212 \\
\cline { 2 - 5 } & $R^{2}$ & 24.3687 & 29.5518 & 35.0069 \\
\hline \multirow{3}{*}{ Elovich } & $A[\mathrm{~g} /(\mu \mathrm{g} \cdot \mathrm{min})]$ & 0.7530 & 0.7988 & 0.7835 \\
\hline
\end{tabular}

and intra-particle diffusion model, respectively; $C$ is the boundary layer thickness; and $\alpha$ [g/( $\mu \mathrm{g} \cdot \mathrm{min})]$ and $\beta(\mathrm{g} / \mu \mathrm{g})$ are the Elovich rate constants.

The kinetic curves of atrazine adsorption onto SMB650 are shown in Fig. 5, and the parameters of these kinetics models were obtained by regression analysis and listed in Table 2. As can be seen in Table 2, the pseudo second-order model fit the data best with their decision coefficients $\left(R^{2}\right)$ greater than 0.98.The experimental adsorption amounts of atrazine $\left(q_{\mathrm{e}-\exp }: 930.175,1110.369\right.$ and $\left.1303.006 \mu \mathrm{g} / \mathrm{g}\right)$ were very close to the calculated values $\left(q_{\text {e-theory }}\right)$ from the pseudo second-order model. Their relative errors were only $5.30 \%, 5.29 \%$ and $6.88 \%$, respectively. Thus, it was more appropriate to describe the adsorption process of atrazine adsorption by the pseudo second-order model. It indicated that both atrazine concentration and SMB650 dosage had influences on

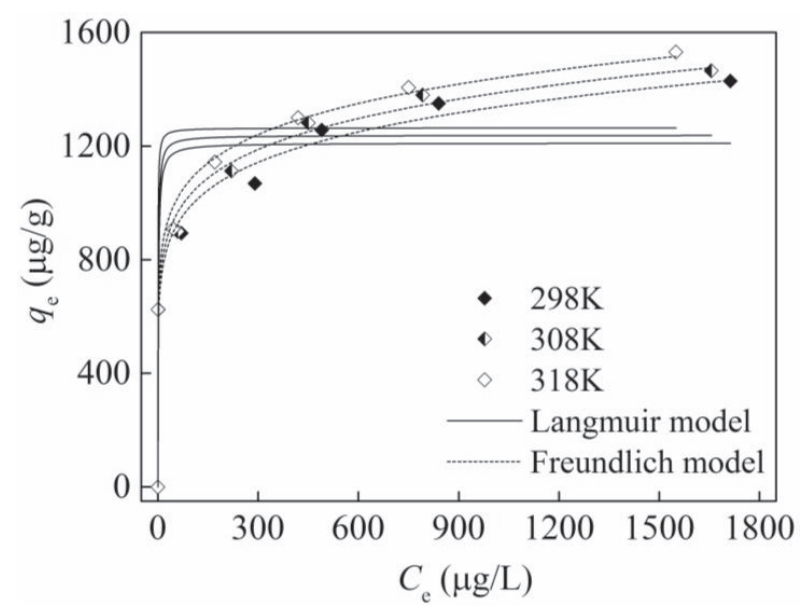

Fig. 6. Adsorption isotherms of atrazine onto SMB650. the adsorption behavior under selected conditions [9]. It also indicated that the liquid film diffusion, surface adsorption and intra-particle diffusion might all play a role in the adsorption of atrazine onto SMB650 [28]. In addition, the fitting curve of the intra-particle diffusion model didn't pass through the origin point of coordinate axis $(\mathrm{C} \neq 0)$, indicating that intra-particle diffusion was not the only dominant rate-controlling step in the adsorption process [29].

\section{Adsorption Isotherms}

In order to further reveal the essence of the interactions between adsorbate and adsorbent, batch experiments were performed under different initial atrazine concentrations (1000, 1500, 2000, 2500, 3000 and $4000 \mu \mathrm{g} / \mathrm{L})$ and temperatures $\left(25,35\right.$ and $\left.45^{\circ} \mathrm{C}\right)$. The adsorption data was processed by the Langmuir and

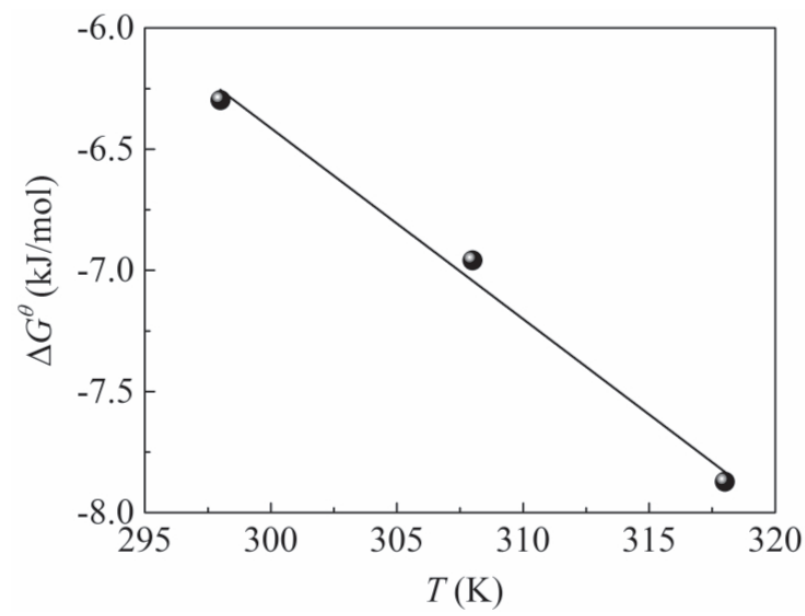

Fig. 7. Relationship between $\Delta G^{\theta}$ and $T$. 
Table 3. Langmuir and Freundlich isotherm parameters for atrazine adsorption.

\begin{tabular}{|c|c|c|c|c|c|c|}
\hline \multirow{2}{*}{$T(\mathrm{~K})$} & \multicolumn{3}{|c|}{ Langmuir model } & \multicolumn{3}{c|}{ Freundlich model } \\
\cline { 2 - 7 } & $q_{\mathrm{m}}$ & $K_{\mathrm{L}}$ & $R^{2}$ & $K_{\mathrm{F}}$ & $1 / n$ & $R^{2}$ \\
\hline 298 & 1210.527 & 0.6768 & 0.8608 & 546.725 & 0.1293 & 0.9891 \\
\hline 308 & 1237.871 & 0.9170 & 0.8579 & 575.826 & 0.1269 & 0.9926 \\
\hline 318 & 1263.875 & 2.0371 & 0.8422 & 619.518 & 0.1217 & 0.9923 \\
\hline
\end{tabular}

Freundlich models. The expressions of Langmuir and Freundlich models can be written as follows:

Langmuir model: $\mathrm{q}_{e}=\mathrm{q}_{m} K_{L} C_{e} /\left(1+K_{L} C_{e}\right)$

Freundlich model: $q_{e}=K_{F} C_{e}^{1 / n}$

...where $K_{L}(\mathrm{~L} / \mu \mathrm{g})$ is the Langmuir adsorption equilibrium constant; $q_{\mathrm{e}}(\mu \mathrm{g} / \mathrm{g})$ is the equilibrium adsorption capacity of adsorbent; $q_{\mathrm{m}}(\mu \mathrm{g} / \mathrm{g})$ is the theoretical maximum adsorption capacity of adsorbent; $C_{\mathrm{e}}(\mu \mathrm{g} / \mathrm{L})$ is the concentration of adsorbate at equilibrium; $K_{F}$ is the adsorption or distribution coefficient of Freundlich model; and $1 / n$ is the heterogeneity factor.

The results of atrazine removal were shown in Fig. 6. As could be seen from Fig. 6, the adsorption capacity of SMB650 for atrazine increased with the increase of initial atrazine concentration. This was due to the increase of initial atrazine concentration, leading to the increase of atrazine molecules around the biochar, which augmented the mass transfer power and thus increased the adsorption amount [30]. Besides, the adsorption amount of atrazine by SMB650 increased with the increase of temperature. When the initial ATZ concentration, solution $\mathrm{pH}$ and SMB650 dosage were respectively $1500 \mu \mathrm{g} / \mathrm{L}, 3.0$ and $1.6 \mathrm{~g} / \mathrm{L}$, the ATZ adsorption amounts were 893.538, 900.343 and $908.594 \mu \mathrm{g} / \mathrm{g}$ with the removal efficiency of $95.3 \%$, $96.0 \%$ and $96.9 \%$ when the temperatures were respectively 25,35 and $45^{\circ} \mathrm{C}$.

The relevant fitting parameters of Langmuir and Freundlich models are listed in Table 3. According to Table 3, the fitting results of Freundlich model were significantly better than those of Langmuir model, and their decision coefficients (R2) were all greater than 0.98 , indicating that the adsorption behavior of atrazine onto SMB650 was more consistent with the Freundlich model and belonged to the multi-molecular layer adsorption. Based on previous studies [31, 32], the constant KF of the Freundlich model represented the quantity of atrazine adsorbed onto SMB650 for unit equilibrium concentration. In this study, the value of KF rose with the increase of temperature, indicating that the high temperature was favorable to the adsorption. In addition, the constant $1 / \mathrm{n}$ of the Freundlich model reflected the heterogeneity of adsorption surface. The adsorption process was more difficult to make happen when the value of $1 / \mathrm{n}$ was greater than 1.0 , while the process was comparatively easier when the value of $1 / \mathrm{n}$ was maintained around 0.1 to 0.5 [33]. In this study, the values of $1 / \mathrm{n}$ were $0.1293,0.1269$ and 0.1217 , respectively, indicating that the adsorption of atrazine onto SMB650 was relatively easy to happen.

\section{Adsorption Thermodynamics}

To understand the nature of the adsorption behavior, the thermodynamic parameters for atrazine adsorption onto SMB650 were calculated using the following equations.

$$
\begin{gathered}
\Delta G^{\theta}=\Delta H^{\theta}-T \Delta S^{\theta} \\
\ln K_{d}=\Delta S^{\theta} / R-\Delta H^{\theta} / R T
\end{gathered}
$$

...where $\Delta G^{\theta} \quad(\mathrm{kJ} / \mathrm{mol}), \Delta H^{\theta} \quad(\mathrm{kJ} / \mathrm{mol})$ and $\Delta S^{\theta}$ $[\mathrm{kJ} /(\mathrm{mol} \cdot \mathrm{K})]$ stand for the changes of free energy, enthalpy and entropy, respectively; $R$ stands for the ideal gas constant $[8.314 \mathrm{~J} /(\mathrm{mol} \cdot \mathrm{K})]$; and $K_{d}$ stands for the thermodynamic equilibrium constant at Kelvin temperature $T(\mathrm{~K})$.

The relationship between $\Delta G^{\theta}$ and $T$ was shown in Fig. 7, and the thermodynamic parameters for atrazine adsorption on SMB650 are shown in Table 4. The values of $\Delta G^{\theta}$ were all negative, indicating that the adsorption process of atrazine onto SMB650 was thermodynamically spontaneous [34, 35]. In addition, the value of $\Delta G^{\theta}$ decreased from -6.2976 to $-7.8730 \mathrm{~kJ} / \mathrm{mol}$ as the temperature increased from

Table 4. Thermodynamic parameters for the removal of atrazine by SMB650.

\begin{tabular}{|c|c|c|c|c|c|}
\hline$T(\mathrm{~K})$ & $K_{d}$ & $\Delta G^{\theta}$ & $\Delta H^{\theta}$ & $\Delta S^{\theta}$ & $R^{2}$ \\
\cline { 1 - 3 } 298 & 12.7031 & -6.2976 & \multirow{2}{*}{17.2179} & \multirow{2}{*}{0.0788} & 0.9830 \\
\hline 308 & 15.1440 & -6.9590 & & \\
\hline
\end{tabular}


$298 \mathrm{~K}$ to $318 \mathrm{~K}$, representing the fact that higher temperature was favorable to the adsorption reaction [35]. The value of $\Delta H^{\theta}(17.2179 \mathrm{~kJ} / \mathrm{mol})$ was found to be positive, revealing that atrazine adsorption onto SMB650 was an endothermic process [36]. Based on the previous studies [37-39], the higher values of $\Delta H^{\theta}$ $(>40 \mathrm{~kJ} / \mathrm{mol})$ were characteristic of chemical adsorption, while the lower values of $\Delta H^{\theta}(<25 \mathrm{~kJ} / \mathrm{mol})$ indicated that the reaction was physical. Therefore, the adsorption of atrazine onto SMB650 was mainly a physical process. The value of $\Delta S^{\theta}[0.0788 \mathrm{~kJ} /(\mathrm{mol} \cdot \mathrm{K})]$ was also positive, confirming that the adsorption was a process of entropy increasing and the degree of chaos between the solid and liquid interface increased [40].

\section{Conclusions}

The biochar was prepared by sheep manure at the pyrolysis temperature of $650^{\circ} \mathrm{C}$, and its potential to remove atrazine from aqueous solution was investigated using batch experiments. The physicochemical properties of SMB650 showed that it had a good foundation for atrazine adsorption. The adsorption reached equilibrium at $500 \mathrm{~min}$ with the atrazine adsorption amount of $893.538 \mu \mathrm{g} / \mathrm{g}$ and the removal efficiency of $95.3 \%$ when the initial atrzaine concentration, initial solution $\mathrm{pH}$, SMB650 dosage and temperature were respectively $1500 \mu \mathrm{g} / \mathrm{L}, 3.0,1.6 \mathrm{~g} / \mathrm{L}$ and $25^{\circ} \mathrm{C}$. The pseudo secondorder and the Freundlich model could more accurately describe the adsorption behavior of atrazine onto SMB650. The calculated thermodynamic parameters indicated that the atrazine adsorption onto SMB650 was a spontaneous and endothermic process. In conclusion, SMB650 was found to be an innovative, efficient and low-cost adsorbent for the removal of atrazine in wastewater.

\section{Acknowledgements}

This study was financially supported by the Science and Technology Project of Sichuan Province under grant No. 2017GZ0375, the Key Project of Education Department in Sichan Province under grant No. 17ZB0031, and the Technology Research and Development Project of Chengdu under grant No. 2015-HM01-00333-SF.

\section{Conflict of Interest}

The authors declare no conflict of interest.

\section{References}

1. THORPE N., SHIRMOHAMMADI A. Herbicides and nitrates in groundwater of Maryland and childhood cancers: A geographic information systems approach. J. Environ. Sci. Heal C. 23, 261, 2005.

2. BARCO-BONILLA N., ROMERO-GONZALEZ R., PLAZA-BOLANOS P., VIDAL J.L.M., FRENICH A.G. Systematic study of the contamination of wastewater treatment plant effluents by organic priority compounds in Almeria province (SE Spain). Sci. Total Environ. 447, 381, 2013.

3. MORENO-GONZALEZ R., CAMPILLO J.A., GARCIA V., LEON V.M. Seasonal input of regulated and emerging organic pollutants through surface watercourses to a Mediterranean coastal lagoon. Chemosphere. 92 (3), 247, 2013.

4. SINGH S., KUMAR V., CHAUHAN A., DATTA S., WANI A.B., SINGH N., SINGH J. Toxicity, degradation and analysis of the herbicide atrazine. Environ. Chem. Lett. 2, 1, 2017.

5. LASSERRE J.P., FACK F., SERCHI T., REVETS D., PLANCHON S., RENAUT J., HOFFMANN L., GUTLEB A.C., MULLER C.P., BOHN T. Atrazine and pcb 153 and their effects on the proteome of subcellular fractions of human MCF-7 cells. Bba-Proteins Proteom. 1824, 833, 2012.

6. ZHAO X.C., OUYANG W., HAO F.H., LIN C.Y., WANG F.L., HAN S., GENG X.J. Properties comparison of biochars from corn straw with different pretreatment and sorption behaviour of atrazine. Bioresource Technol. 147, 338, 2013

7. PAL J., DEB M.K., SIRCAR J.K., AGNIHOTRI P.K. Microwave green synthesis of biopolymer-stabilized silver nanoparticles and their adsorption behavior for atrazine. Appl. Water Sci. 5, 181, 2015.

8. WANG P.F., YIN Y.Y., GUO Y., WANG C. Preponderant adsorption for chlorpyrifos over atrazine by wheat strawderived biochar: experimental and theoretical studies. Rsc Adv. 6, 10615, 2016.

9. ALAHABADI A., MOUSSAVI G. Preparation, characterization and atrazine adsorption potential of mesoporous carbonate-induced activated biochar (CAB) from Calligonum Comosum biomass: Parametric experiments and kinetics, equilibrium and thermodynamic modeling. J. Mol. Liq. 242, 40, 2017.

10. MOREIRA A.J., BORGES A.C., GOUVEA L.F.C., MACLEOD T.C.O., FRESCHI G.P.G. The process of atrazine degradation, its mechanism, and the formation of metabolites using UV and UV/MW. J. Photoch. Photobio. A. 347, 160, 2017.

11. YANG J.X., LI J., DONG W.Y., MA J., CAO J., LI T.T., LI J.Y., GU J., LIU P.X. Study on enhanced degradation of atrazine by ozonation in the presence of hydroxylamine. J. Hazard. Mater. 316, 110, 2016.

12. CHENG M., ZENG G.M., HUANG D.L., LAI C., XU P., ZHANG C., LIU Y., WAN J., GONG X.M., ZHU Y. Degradation of atrazine by a novel Fenton-like process and assessment the influence on the treated soil. J. Hazard. Mater. 312, 184, 2016.

13. QIU Y.P., ZHENG Z.Z., ZHOU Z.L., SHENG G.D. Effectiveness and mechanisms of dye adsorption on a straw-based biochar. Bioresource Technol. 100, 5348, 2009.

14. YANG G.X., JIANG H. Amino modification of biochar for enhanced adsorption of copper ions from synthetic wastewater. Water Res. 48, 396, 2014.

15. WANG Z.H., SHEN D.K., SHEN F., LI T.Y. Phosphate adsorption on lanthanum loaded biochar. Chemosphere. 150, 1, 2016. 
16. TAN G.C., SUN W.L., XU Y.R., WANG H.Y., XU N. Sorption of mercury (II) and atrazine by biochar, modified biochars and biochar based activated carbon in aqueous solution. Bioresource Technol. 211, 727, 2016.

17. ZHANG W.H., ZHENG J., ZHENG P.P., Qiu R.L. Atrazine immobilization on sludge derived biochar and the interactive influence of coexisting $\mathrm{Pb}(\mathrm{II})$ or $\mathrm{Cr}(\mathrm{VI})$ ions. Chemosphere. 134, 438, 2015.

18. ZHAO L., DONG Y.H., WANG H. Residues of veterinary antibiotics in manures from feedlot livestock in eight provinces of China. Sci. Total Environ. 408, 1069, 2010.

19. CANG L., WANG Y.J., ZHOU D.M., DONG Y.H. Heavy metals pollution in poultry and livestock feeds and manures under intensive farming in Jiangsu Province, China. J. Environ. Sci.-China. 16, 371, 2004.

20. XIONG X.O., LI Y.X., LI W., LIN C.Y., HAN W., YANG M. Copper content in animal manures and potential risk of soil copper pollution with animal manure use in agriculture. Resour. Conserv. Recy. 54, 985, 2010.

21. MANDAL A., SINGH N., PURAKAYASTHA T.J. Characterization of pesticide sorption behaviour of slow pyrolysis biochars as low cost adsorbent for atrazine and imidacloprid removal. Sci. Total Environ. 577, 376, 2017.

22. FENG D., YU H.M., DENG H., LI F.Z., GE C.J. Adsorption characteristics of norfloxacin by biochar prepared by cassava dreg: kinetics, isotherms, and thermodynamic analysis. Bioresources. 10, 6751, 2015.

23. QIAN J., SHEN M.M., WANG P.F., WANG C., LI K., LIU J.J., LU B.H., TIAN X. Perfluorooctane sulfonate adsorption on powder activated carbon: Effect of phosphate (P) competition, $\mathrm{pH}$, and temperature. Chemosphere. 182, $215,2017$.

24. WANG, L., CHEN, G.C., LING, C., ZHANG, J.F., SZERLAG, K. Adsorption of Ciprofloxacin on to Bamboo Charcoal: Effects of pH, Salinity, Cations, and Phosphate. Environ. Prog. Sustain. 36, 1108, 2017.

25. WEI Z.G., LIANG K., WU Y., ZOU Y.D., ZUO J.H., ARRIAGADA D.C., PAN Z.C., HU G.H. The effect of pH on the adsorption of arsenic(III) and arsenic(V) at the $\mathrm{TiO}_{2}$ anatase [101] surface. J. Colloid Interf. Sci. 462, 252, 2016.

26. KARA S., AYDINER C., DEMIRBAS E., KOBYA M., DIZGE N. Modeling the effects of adsorbent dose and particle size on the adsorption of reactive textile dyes by fly ash. Desalination. 212, 282, 2007.

27. YANG S.T., LI J.X., SHAO D.D., HU J., WANG X.K. Adsorption of $\mathrm{Ni}(\mathrm{II})$ on oxidized multi-walled carbon nanotubes: Effect of contact time, $\mathrm{pH}$, foreign ions and PAA. J. Hazard. Mater. 166, 109, 2009.

28. HO Y.S. Review of second-order models for adsorption systems. J. Hazard. Mater. 136, 681, 2006.
29. EL BOURAIE M., MASOUD A.A. Adsorption of phosphate ions from aqueous solution by modified bentonite with magnesium hydroxide $\mathrm{Mg}(\mathrm{OH})_{2}$. Appl. Clay. Sci. 140, 157, 2017.

30. ALJEBOREE A.M., ALKAIM A.F., AL-DUJAILI A.H. Adsorption isotherm, kinetic modeling and thermodynamics of crystal violet dye on coconut huskbased activated carbon. Desalin. Water Treat. 53, 3656, 2015.

31. ALEMAYEHU E., THIELE-BRUHN S., LENNARTZ B. Adsorption behaviour of $\mathrm{Cr}(\mathrm{VI})$ onto macro and microvesicular volcanic rocks from water. Sep. Purif. Technol. 78, 55, 2011.

32. KYZAS G.Z., DELIYANNI E.A., MATIS K.A. Activated carbons produced by pyrolysis of waste potato peels: Cobalt ions removal by adsorption. Colloid Surface A. 490, 74, 2016.

33. NAMASIVAYAM C., KAVITHA D. Removal of Congo Red from water by adsorption onto activated carbon prepared from coir pith, an agricultural solid waste. Dyes Pigments. 54 (1), 47, 2002.

34. ABIGAIL M.E.A., CHIDAMBARAM R. Rice husk as a low cost nanosorbent for 2,4-dichlorophenoxyacetic acid removal from aqueous solutions. Ecol. Eng. 92, 97, 2016.

35. MOUSSAVI G., HOSSEINI H., ALAHABADI A. The investigation of diazinon pesticide removal from contaminated water by adsorption onto $\mathrm{NH}_{4} \mathrm{Cl}$-induced activated carbon. Chem. Eng. J. 214, 172, 2013.

36. ALI I., ALOTHMAN Z.A., AL-WARTHAN A. Sorption, kinetics and thermodynamics studies of atrazine herbicide removal from water using iron nano-composite material. Int. J. Environ. Sci. Te. 13, 733, 2016.

37. GUPTA V.K., PATHANIA D., SHARMA S., SINGH P. Preparation of bio-based porous carbon by microwave assisted phosphoric acid activation and its use for adsorption of Cr(VI). J. Colloid Interf. Sci. 401, 125, 2017.

38. LI Y.H., DI Z.C., DING J., WU D.H., LUAN Z.K., ZHU Y.Q. Adsorption thermodynamic, kinetic and desorption studies of $\mathrm{Pb}^{2+}$ on carbon nanotubes. Water Res. 39, 605, 2005.

39. CHOWDHURY S., MISHRA R., SAHA P., KUSHWAHA P. Adsorption thermodynamics, kinetics and isosteric heat of adsorption of malachite green onto chemically modified rice husk. Desalination. 265, 159, 2011.

40. JOHIR M.A.H., PRADHAN M., LOGANATHAN P., KANDASAMY J., VIGNESWARAN S. Phosphate adsorption from wastewater using zirconium (IV) hydroxide: Kinetics, thermodynamics and membrane filtration adsorption hybrid system studies. J. Environ. Manage. 167, 167, 2016. 